\title{
Recovering Phosphorus from Soil: A Root Solution?
}

\author{
Marc I. Stutter, ${ }^{*}{ }^{\dagger}$ Charles A. Shand, ${ }^{\dagger}$ Timothy S. George, ${ }^{\dagger}$ Martin S. A. Blackwell, ${ }^{\dagger}$ Roland Bol, ${ }^{\ddagger}$ \\ Regina L. MacKay, ${ }^{\S}$ Alan E. Richardson, $"$ Leo M. Condron, ${ }^{\perp}$ Benjamin L. Turner, \\ and Philip M. Haygarth ${ }^{\$}$ \\ ${ }^{\dagger}$ The James Hutton Institute, Aberdeen, AB15 8QH, U.K. and Dundee, DD2 5DA, U.K. \\ ${ }^{\ddagger}$ Rothamstead Research North Wyke, Devon, EX20 2SB, U.K. \\ ${ }^{\S}$ College of Life Sciences, University of Dundee, Dundee, DD1 5EH, U.K. \\ "CSIRO Plant Industry, Black Mountain, Canberra, ACT 2601, Australia \\ ${ }^{\perp}$ Faculty of Agriculture and Life Sciences, Lincoln University, Lincoln 7647, Canterbury, New Zealand \\ ${ }^{\#}$ Smithsonian Tropical Research Institute, Republic of Panama \\ \$Lancaster Environment Centre, Lancaster University, LA1 4YQ U.K.
}

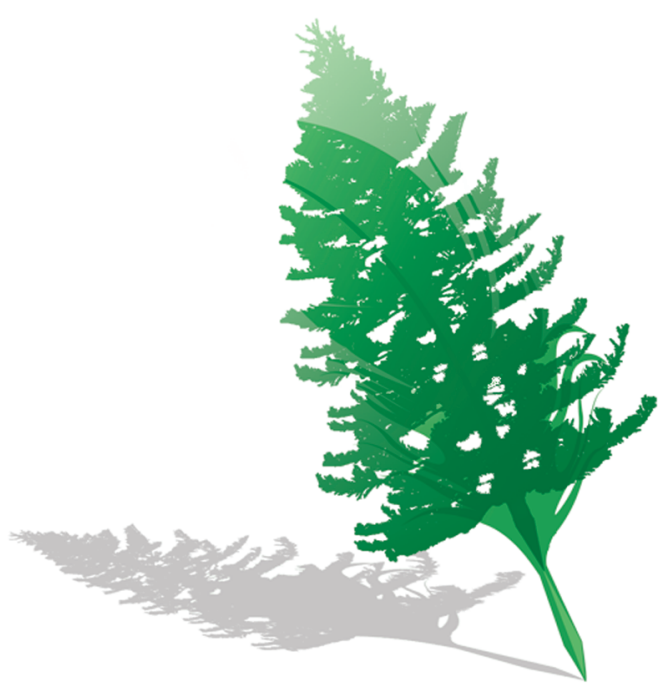

$\mathrm{P}$ hosphorus $(\mathrm{P})$ is crucial to modern agricultural production, but access to geographically concentrated global reserves of phosphate rock is politically sensitive and economically challenging. ${ }^{1}$ The use of mined rock phosphate as a principal $\mathrm{P}$ source for chemical fertilizers facilitated last century's agronomic revolution, but increased our dependence on this nonrenewable P source to unsustainable levels. ${ }^{2}$ The plant availability of phosphate fertilizer is reduced by sorption and organic complexation in the soil, so fertilizer applications greater than the amount required by the crop are used to counteract the strong binding of the phosphate to the soil matrix. ${ }^{3}$ This has greatly increased the $\mathrm{P}$ content of managed soils, ${ }^{3}$ many of which now contain sufficient $P$ reserves to potentially buffer threats to food security for many decades.

Overapplication of $\mathrm{P}$ fertilizer to soil is in itself wasteful, but the transport of $\mathrm{P}$ to watercourses by erosion is also causing widespread problems of eutrophication. We argue that research should be targeted urgently toward capitalizing on the accumulated soil $\mathrm{P}$ reserves by improving $\mathrm{P}$ bioavailability and utilization by crops, while simultaneously developing more efficient use strategies for rock phosphate, manures, composts, and wastes. A fundamental stage in realizing the magnitude and value of the current global soil $\mathrm{P}$ resource is appreciating the range of complexed $\mathrm{P}$ forms in soil and their specific issues for crop P accessibility. Soil organic $\mathrm{P}$ is especially poorly considered in terms of amounts and future utility. Learning to better utilize all of the different residual $\mathrm{P}$ forms in soil is essential to providing a sustainable cycle between agricultural inputs and plant uptake, akin to more natural systems.

Residual soil P (that becoming stabilized within soils) includes a range of chemical forms. Most research related to improving phosphorus recovery has considered only the accumulated inorganic orthophosphate forms in the soil. Yet a considerable amount of phosphate becomes incorporated into organic compounds such as monoesters, diesters (e.g., DNA), and polyphosphates (e.g., ATP). Some orthophosphate monoesters are stabilized in soils due to a high charge density or formation of metal ion salts, such that large reserves have accumulated in many soils. ${ }^{4}$ A review of global arable and intensive grassland topsoil $\mathrm{P}$ data shows the accumulation of soil $\mathrm{P}$ in inorganic and organic forms (Figure 1). Countries such as the United States, Canada, and Germany, where intensive agriculture relies on large fertilizer inputs, have soils that contain large proportions of inorganic orthophosphate, but worldwide, organic P forms make important contributions to topsoil stocks. UK data (Figure 1, dominated by pasture soils) show a large monoester contribution of $54 \%$ to the extractable $\mathrm{P}$ total. Global averages across arable and pasture soils ranged from 24\% (Germany) to 59\% (Ethiopia). Organic P therefore warrants attention as a quantitatively important soil $\mathrm{P}$ resource.

Developing agricultural systems to use these soil $\mathrm{P}$ reserves will mark the start of a process of reducing the dependency on excessive applications of mined $\mathrm{P}$ fertilizers to sustain production. However, new $\mathrm{P}$ use strategies must be able to maintain food production to sustain the world's population, predicted to rise to 9 billion by $2050 .{ }^{1}$ Evidence is required to show that withholding fertilizer from agricultural soils will not suppress crop yields, because productivity can be fueled by utilization of residual inorganic and organic $\mathrm{P}$ forms. Both these $\mathrm{P}$ forms accumulate in soils but require different approaches to realizing their use. Many staple crops appear poor at accessing organic $\mathrm{P}$, having been bred and selected for compatibility with

Published: January 20, 2012 


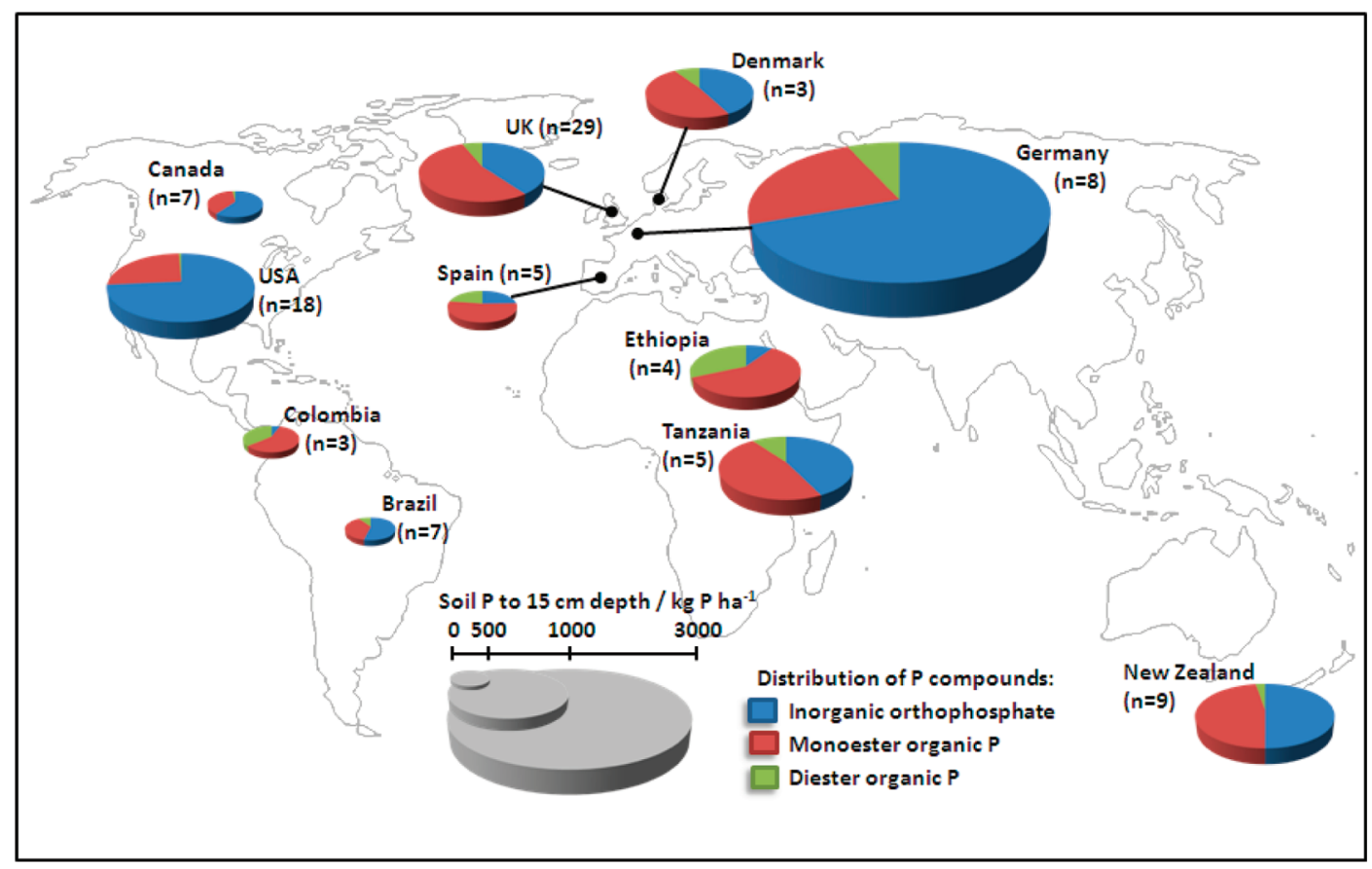

Figure 1. Agricultural soil total $\mathrm{P}$ concentrations and distribution of $\mathrm{P}$ compounds. Pie-chart segments denote $\mathrm{P}$ compound distributions as means of the extract $\mathrm{P}$ data $\left(n=\right.$ number of soils per country), taken from thirteen literature sources using soil ${ }^{31} \mathrm{P}$ NMR studies, as cited at http:// www.hutton.ac.uk/publications/marc-stutter-viewpoint-environmental-science-and-technology.

inorganic fertilizer use. However, some plants possess strategies to access stabilized $\mathrm{P}$ through the exudation of organic anions into the rhizosphere to solubilize P compounds, and enzymes to mineralize organic $\mathrm{P}$ to orthophosphate for plant uptake. Recent research has demonstrated the possibility of enhancing organic $\mathrm{P}$ use by crop plants, both by genetic manipulation and conventional selection and breeding to introduce traits of specialist natural plants. ${ }^{5}$ Complementary research areas include engineering root architecture and inoculating roots with fungi and bacteria to mobilize stabilized P. By using strategies taken from natural plant-soil-microbial systems, crucial steps are being taken to break the bottleneck caused by the stabilization of $\mathrm{P}$ compounds in soils.

Unlocking the residual $\mathrm{P}$ already bound to soils is an essential stage in a sustainable future for agriculture, and one which buys vital decades for development of longer term solutions. Such future plans must necessarily be based on more "closed" systems of nutrient recycling and reuse, instead of the current situation where mined $\mathrm{P}$ passes inefficiently through the human food chain into waste waters and to the oceans. ${ }^{2}$ This combination of approaches in crop soil $\mathrm{P}$ acquisition and societal $\mathrm{P}$ resource use efficiency can provide a truly sustainable $\mathrm{P}$ future. However, future alternate $\mathrm{P}$ fertilizer materials will likely comprise organic nutrient forms and/or complexes with recovery process coagulants such as iron compounds. Therefore, overcoming today's scientific issues for crops to efficiently utilize complexed soil $\mathrm{P}$ reserves provides the tools to maximize production efficiencies from tomorrow's reclaimed $\mathrm{P}$ materials. This raises the importance of action now to improve our biotechnological approaches in agronomy and appreciation of complexed $\mathrm{P}$ reserves in soils.

\section{AUTHOR INFORMATION}

\section{Corresponding Author}

*E-mail: marc.stutter@hutton.ac.uk.

\section{REFERENCES}

(1) Godfray, H. C. J.; Beddington, J. R.; Crute, I. R.; Haddad, L.; Lawrence, D.; Muir, J. F.; Pretty, J.; Robinson, S.; Thomas, S. M.; Toulmin, C. Food security: The challenge of feeding 9 billion people. Science 2010, 327, 812-818.

(2) Elser, J.; Bennett, E. M. A broken biogeochemical cycle. Nature 2011, 478, 29-31.

(3) MacDonald, G. K.; Bennett, E. M.; Potter, P. A.; Ramankutty, N. Agronomic phosphorus imbalances across the world's croplands. Proc. Natl. Acad. Sci. U.S.A. 2011, 108, 3086-3091.

(4) Condron, L. M.; Tiessen, H. Interactions of organic phosphorus in terrestrial ecosystems. In Organic Phosphorus in the Environment; Turner, B. L., Frossard, E., Baldwin, D. S., Eds.; CABI: UK, 2005, 295-307.

(5) Richardson, A. E.; Hocking, P. J.; Simpson, R. J.; George, T. S. Plant mechanisms to optimize access to soil phosphorus. Crop Pasture Sci. 2009, 60, 124-143. 